УдК 336.22

\author{
A. Ivashchenko, \\ PbD in Economics, Associate Professor, Corporate Finance and Controlling Department, \\ Kyiv National Economic University named after $V$. Hetman \\ ORCID ID: 0000-0002-4599-7137 \\ G. Sudak, \\ Master Student of Program "Corporate Financial Management", \\ Kyiv National Economic University named after Vadym Hetman \\ ORCID ID: 0000-0001-5355-657X
}

DOI: $10.32702 / 2306-6814.2019 .24 .67$

\title{
BLOCKCHAIN TECHNOLOGY AND KEY FEATURES OF ITS POSSIBLE IMPLEMENTATION INTO UKRAINIAN TAX SYSTEM
}

\author{
А. І. Іващенко, \\ к. е. н., доцент кафедри корпоративних фінансів і контролінгу, \\ АВНЗ "Київський національний економічний університет імені В. Гетьмана" \\ Г. Г. Судак, \\ магістрант програми "Фінансовий менеджмент у сфері бізнесу", \\ АВНЗ "Київський національний економічний університет імені В. Гетьмана"
}

\section{ТЕХНО АОГІЯ БАОКЧЕЙН ТА ОСОБАИВОСТІ ІІЇ ВПРОВААЖЕННЯ В УКРАЇНСЬКУ ПОААТКОВУ СИСТЕМУ}

The article deals with the study of the essence of Blockchain technology and its possible implementation into Ukrainian tax system. Taking into account current economic and political situation in Ukraine, the paper considers the advantages of Blockchain as one of the most prospective methods of improvements and at the same time simplifications in Ukraine's the tax system for both, the state and taxpayers.

The main attention of the research was paid to the features of Blockchain implementation into tax administration exemplified as data structuring, Cost-efficiency, security (tamper detection), decentralized bookkeeping technology (transparency), verifying transfer pricing and applying smart contracts.

The authors classified countries by criterion of using electronic invoicing in jurisdiction as follows as allowed, not allowed, not applicable and no regulation. It was defined that Blockchain technology owns the capacity to reconstruct accounting and automate the method of payments, transfer, and recordkeeping of assets.

The paper was focused on VAT collection and its return via Blockchain which might bring such benefits to tax system as transaction confirmation could be performed immediately; no duplication; lack of fraud and existing multi-dimensional check; increasing trustworthiness by using digital signature.

The successful cases of Blockchain implementation into public services were considered namely pilot program in city Innisfil (Canada), in which local residents can pay their taxes in cryptocurrency; by using blockchain technologies, National Agency of Public Registry in the Republic of Georgia can provide its citizens with a digital certificate of their assets, supported with cryptographical proof published to the Bitcoin Blockchain; Exonum Blockchain could be considered as an intermediary layer between the backend system and the front-end interface for users, where all transactions are verified using smart-contracts and then logged permanently into the blockchain.

To conclude authors identified such potential benefits of blockchain implementation into tax administration as transactional costs reduction, a more streamlined, efficient and effective tax function.

У статті розглядається сутність технології Blockchain та її можливе впровадження в українську податкову систему. Враховуючи сучасну економічну та політичну ситуацію в Україні, дослідження присвячено перевагам Blockchain як одномуз найбільш перспективних методів вдосконалення та одночасно спрощення податкової системи України якдля держави, так і для платників податків.

Основну увагу дослідження було приділено особливостям впровадження Blockchain у податковому адмініструванні, наприклад, структурування даних, економічність, безпека (виявлення фаль- 
сифікацій), децентралізована технологія бухгалтерського обліку (прозорість), перевірка трансфертного ціноутворення та застосування розумних контрактів.

Автори класифікували країни за критеріями використання електронних рахунків-фактур у юрисдикції на такі типи, як країни, де це дозволено, не дозволено, не застосовується та не регламентується. Було визначено, що технологія Blockchain володіє здатністю реконструювати облік та автоматизувати метод платежів, переказів та обліку активів.

Предметом статті є збор ПДВ та його відшкодування через Blockchain, що може принести такі вигоди податковій системі, як негайне підтвердження угоди; відсутність дублювання; відсутність шахрайства та наявність багатовимірної перевірки; підвищення надійності за допомогою цифрового підпису.

Успішні випадки впровадження Blockchain у державні послуги були розглянуті, а саме - пілотна програма у місті Іннісвіл (Канада), в якій місцеві жителі можуть сплачувати податки в криптовалюті; використовуючи технології blockchain, Національне агентство державного реєстру в Республіці Грузія може надати своїм громадянам цифровий сертифікат їх активів, підкріплений криптографічним доказом, опублікованим у Bitcoin Blockchain; Blockchain Exonum може розглядатися як посередницький рівень між системою бек-енду та інтерфейсним інтерфейсом для користувачів, де всі транзакції перевіряються за допомогою смарт-контрактів і потім постійно входять у блокчейн.

У висновках автори визначили такі потенційні переваги впровадження блокчейна в податкове адміністрування, як зменшення транзакційних витрат, більш швидку, прозору та ефективну функцію оподаткування.

Key words: FinTech, Blockchain, smart contract, tax system, taxes, taxpayer, authorities, value added tax, electronic payment, invoice.

КлючоВі слова: Fin Tech, Blockchain, розумний контракт, податкова система, податки, платник податкіВ, органи Влади, податок на додану Вартість, електронний платіж, рахунок-фьактура.

\section{INTRODUCTION}

One of the most common scientific topics is tax issues and ways of its optimization and administration improvement. It's obvious, that every tax system can be developed considering the fact that taxes can be used as regulative instruments as well as stimulating ones. Due to the fact, that taxes have the largest share of state revenues, though, the ways of tax system improvement should not be underestimated.

\section{LITERATURE REVIEW}

Many scholars in writings expressed their views on the FinTech technologies and its implementation into state's tax system, among them P. Jurowiec, A. Seco, J.K. Liu, M. Porter, G. Jurgen, I. Longarte should be underlined.

OECD considers that Big Data technology offers revenue bodies the opportunity to extract better business value out of existing data. "Investment in new capabilities creates the possibility to develop new and convenient services for taxpayers..." according to OECD [1].

G. Jurgen claimed that blockchain is one of the most hopeful technologies because of its capacity to deliver realtime data for many layers to a large audience, as in the situation with tax.

On the other hand, Kai Stinchcombe argued that tampering with data stored on a blockchain is troublesome, but it's false that blockchain is a good method to create data that has integrity because systems made on trust, standards, and organizations essentially perform better than the kind of no-need-for-trusted-parties systems blockchain envisions.
Scott Cook has been suggested that blockchain may be effective in data science. He concludes that blockchain is set to assist data scientists to achieve many successes that were recently observed as impossible because it has strong protection and straightforward account keeping. Notwithstanding decentralized digital ledgers are yet a beginner technology, the newest outcomes from companies testing them, such as IBM and Walmart, reveals that they work. This article would highlight potential benefits of implementation into the tax system, assuming Ukrainian nowadays circumstances.

Bruce Schneier in his one of the latest articles has been acknowledged the blockchain as ineffective technology and argues that fake belief in blockchain can itself be a safety risk because security difficulties it solves are reasonably not the ones you hold ("manipulating audit data is probably not your major security risk"). One more argument is that incapability, particularly in scaling, are believably not worth it.

On the contrary thoughts against technology, Marco lansiti Karim and R. Lakhani in their work for Harvard Business Review suggested for blockchain much more positive scenario. They said that the aforementioned technology could slash the cost of transactions and reshape the economy. The main idea of their review is that technology at the core of bitcoin and other virtual money is an open, distributed ledger that can document actions efficiently and in a valid and permanent form.

The focus of the given research is the analysis of tax system in Ukraine, therefore, finding the ways for its improvement is among the main goals. This research is 
called to find appropriate methods of improving the tax system of Ukraine using new technologies taking into account timeline (period of time), functions and necessity of taxes and suggest general perspectives.

\section{PRESENTING MAIN MATERIAL}

Implementation of FinTech, namely Blockchain, into different economic spheres are among popular methods for its improvement, so, the tax system is not an exception. This technology has emerged at a time when the redefinition of tax system formation according to the modern tendencies of the digital era is among essentials for its digital improvement excluding any manual processes. The essential characteristic features of tax system should include such categories as transparency, equality, easiness of understanding and use, security. Unfortunately, in Ukraine's we have a lack of all mentioned before basics. For example, the bulk of tax avoidance/ evasion occurs not only in SMEs but also in large businesses. It is not a single phenomenon, but a symptom of more serious problems like high corruption, lack of tax culture (and overall trust in the government), which causes fails in performing the main duty of the tax system. Blockchain could become an alternative way to solve the mentioned issues.

The growth of the sharing economy, digital business, and new business types have produced the need for the tax system automatization. While blockchain is not the cure-all for the tax system, it could be implemented in a fraction of fields to diminish the administrative burden and collect tax at a more moderate cost, helping to narrow the tax gap [2]. Reviewing all mentioned previously, this technology could improve the tax regime by providing such features as:

1. Data structuring - means data storage, in which all data structured in virtual blocks and recording alongside with transactions. The blockchain model works as more data recorded, more transactions executed - more blocks created. Every block is connected with the previous one. The formation of "chain" of blocks is something provides this kind of information composition its clever name.

2. Cost-efficiency - use of a distributed ledger technology possibly decreases expenses of transaction processing and data storage without a mediator.

3. Security (tamper detection) in a blockchain - data saved in the blockchain immutable applying cryptography. Each block is referenced by an individual line of characters, produced by a cryptographic "hash" function. This function can allow any amount of data as input information and produce a settled length series as output. That settled length output is acknowledged as a hash (a hash could look like this: 82e35a613cena37e9652366234c5dd412ga5$86147 \mathrm{f} 1)$. The obligation for collecting sales or revenue tax could, conceivably, change entirely from tax authorities to members in the sharing economy.

4. Decentralized bookkeeping technology (transparency) - the ledger can be shared amongst a certain group of users connected through the local area network, or with thousands across the internet. This technology eliminates the necessity for centralization through an intermediary, allowing parties to share data and transact directly among each other under a secure way. Blockchain makes cheating and mistakes more straightforward to detect because the scheme renders clear data concerning transactions and details in the system. This could be especially helpful in tracing if and where VAT has been settled, and while arranging so diminish VAT scam. It could further improve to encourage behavioral development because of the opportunities and outgrowths of noncompliance. It's also feasible that you'll be caught and forever banned in the blockchain system. Under these policies, it is expected blockchain may help to lower the tax gap to some scale.

5. Verifying transfer pricing - Blockchain serves transactions and could be practiced to transactional taxes, such as VAT, withholding tax, stamp duties, and insurance premium taxes. The system could additionally boost with transfer pricing. For instance, could it codify the considerations created while ascertaining whereby profits are assigned to various components of a business? It was accepted there was nothing to prevent this being made from a technology viewpoint [2].

6. Smart contracts - computer programs that help, confirm or implement the negotiation or fulfilling of an agreement. They usually replicate the logic of general contractual conditions. By smart contracts, various kinds of contractual articles can be done partly or fully selfexecuting, self-enforcing or both [3].

As we see, the aforementioned technology could be valuable for advancing the tax system for every country and Ukraine in particular. It shifts the relationship between taxpayers and tax authorities and changes the way of tax returns 'obtaining. It also leads to a change in tax payment and its information storage.

Blockchain technology owns the capacity to reconstruct accounting and automate the method of payments, transfer, and record-keeping of assets. The potential of digitizing taxes has been notified by numerous countries, and unique solutions appear, such as SAF-T in Europe or real-time automated invoicing in South America. In 2018 EY conducted a survey about e-invoicing requirements in 82 jurisdictions. Among the 82 respondents, their survey indicates that 25 jurisdictions have no regulation related to the electronic invoicing. E-invoicing is mandatory in 10 jurisdictions and is not permitted in 5 jurisdictions (Table 1). Therefore, in most jurisdictions, taxpayers have the choice to adopt electronic invoicing.

Excited by a wish for higher performance and greater compliance, tax authorities try to collect and examine data digitally. Taxpayers likewise demand the method of taxpaying to become more comfortable and less timeconsuming.

There are additional possibilities to deliver greater confidence to tax administration and decrease the opportunity of any conflicts. Consequently, your tax documents and procedure would be agreed up front among the various parties in the system, including negotiations with the tax authorities as a member of the blockchain protocols. Nearly all transactions would be possible to review.

In the prospect, blockchain may be an important part of performing real-time, automated tax processes for both SME and large companies.

A VAT is one of the greatest contributions to administrative budgets. For those purposes, tax authorities are 
Table 1. Possibility of using electronic invoicing in jurisdiction

\begin{tabular}{|l|l|l|l|l|l|}
\hline \multicolumn{2}{|c|}{ Allowed } & \multicolumn{1}{c|}{$\begin{array}{c}\text { Not } \\
\text { allowed }\end{array}$} & $\begin{array}{c}\text { Not } \\
\text { applicable } \\
\text { N/A) }\end{array}$ & $\begin{array}{c}\text { No } \\
\text { Regulation }\end{array}$ \\
\hline Albania & Botswana & Pakistan & Jordan & Belarus & Bahrain \\
\hline Angola & Bulgaria & Papua & Kenya & Brasil & Cambodia \\
\hline Australia & Croatia & Poland & Paraguay & Chile & Iraq \\
\hline Austria & Cyprus & Portugal & Venezuela & Costa Rica & Kuwait \\
\hline Belgium & Denmark & Romania & Zimbabwe & Indonesia & Libya \\
\hline China (mainland) & Estonia & Russia & & Mongolia & \\
\hline Curacao & Finland & Senegal & & Rwanda & Saudi Arabia \\
\hline Czech Republic & Germany & Serbia & & Turkey & Tanzania \\
\hline El Salvador & Guam & Slovakia & & Ukraine & OAE \\
\hline France & Luxembourg & Vietnam & & Urugway & \\
\hline Hong Kong & Macedonia & Slovenia & & & \\
\hline Iceland & Republic of Namibia & South Africa & & & \\
\hline Ireland & Netherlands & Spain & & & \\
\hline Isle of Man Israel & Republic of Latvia & Sri Lanka & & & \\
\hline Italy & Norway & Uganda & & & \\
\hline Kazakhstan & New Guinea & United Kingdom & & & \\
\hline Korea & Philippines & Switzerland & & & \\
\hline Lithuania & Republic of Singapore & Taiwan & & & \\
\hline Malta & Sweden & New Zealand & & & \\
\hline Moldova & & & & & \\
\hline Total & & & & & \\
\hline 58 & & & & & \\
\hline
\end{tabular}

Source: compiled by the authors using the source [4].

looking for methods of more useful its collection in order to obtain higher revenue and reduce the budget gap.

In the current state of VAT - on both state and worldwide level - the way is filled by a diversity of problems. It is very reliant on companies themselves to determine the amount of VAT accurately and submit it to the tax authorities. As tax returns and reimbursements are estimated across a determined period, for example, monthly or quarterly, the computations are not based on exact transactions but preferably on arbitrary dates (for example invoice dates) [5]. Every company must follow and document the VAT they face on purchases that will be resold for obtaining credit for the VAT paid on their tax return. So, blockchain in the VAT collecting could make such benefits as:

- Real-time - both, client and merchant of the VAT related data giving no place for variations. Blockchain technology transactions can be confirmed in real-time making the actual transaction much quicker in comparison with today's processes concerning, stocks, property, assets, etc. between all parties.

- Single-use - since the registration of purchase is processed in real-time for both buyer and seller, there is no possibility for duplication of entries.

- Transparency - transactions performed by smart contracts are tamper evidence and clear, which decrese the risk of fraud and mistakes. The system allows for processing VAT from a transactional point of view, multidimension checks and affirmations of the action, parties of the proceedings and allowed and business meaning of the transaction.

- Digital signature - all transactions have to be digitally signed, making it more trustworthy and safer than it works nowadays with a paper signature or e-mail approvals.

Every year we can see an increase in usage of blockchain technology almost in all spheres, while the most common is finance and trade. Also, blockchain experiments in the public sector have been accelerating on a global scale. There are many examples concerning blockchain and authorities in different countries. One of them is the Ontarian town of Innisfil, Canada. Innisfil's tax authorities in 2019 has launched a pilot program in which local residents can pay their taxes in cryptocurrency, with Bitcoin first and possibly others soon after. This follows a development last year where American residents of the state of Ohio were allowed to pay their taxes in Bitcoin. The project was adopted by Innisfil's council for a year [6].

Next interesting example is using blockchain to obtain a digital certificate of citizen's assets. By using blockchain technologies, National Agency of Public Registry in the Republic of Georgia can provide its citizens with a digital certificate of their assets, supported with cryptographical proof published to the Bitcoin Blockchain. The main goal of the project was to develop the most secure solution to provide citizens and governments with data safety, auditable processes and transparency [7].

The last example of successful Blockchain implementation is Ukrainian experience. The government of Ukraine uses a System of Electronic Trading in Seized Property, or SETAM, to auction confiscated property. This system is being moved onto an Exonum Blockchain that will enhance citizen trust in the system and provide a layer of security. In this project, Exonum would be installed as an intermediary layer between the back-end system and the front-end interface for users. All transactions are verified using smart-contracts and then logged permanently into the blockchain [7].

Any discrepancies between the information stored on the blockchain and in the original database (e.g., SETAM) are monitored and audited. In the case of Bitfury's work with the State Agency of eGovernance of Ukraine, both public notaries, auction participants and the highly respected NGO Transparency International can all audit the blockchain. Finally, the decentralized design of this blockchain-based auction allows for constant accessibility 
to the data, even in case of malfunctioning nodes or bad actors [7].

Moving back to the blockchain in financial sector, one of the famous examples is token issuance. In August 2018. The World Bank, using the Commonwealth Bank of Australia, issued tokens worth $\$ 73 \mathrm{ml}$. Then this project allowed investors to get profitability at the level of $2.2 \%$ per annum. It also annually issues similar securities with the traditional form of issuance for $\$ 50-60$ billion. And its joint project with Commonwealth Bank of Australia can be called a test launch [8].

In February 2019, Spanish Banco Bilbao Vizcaya Argentaria issued $\$ 169$ million worth of bonds on the blockchain to finance environmental projects [8].

Talking about trade, there are quite more interesting ways of using this technology, especially if we will talk about taxes as an integral part of a trade. Hence, we should explore the essence of smart contracts. The origin of smart contracts comes from 1990, but blockchain technology enabled its implementation in a more full and safe way. The main goal of a smart contract is to remove the need for an intermediary and to enable anonymous parties to conduct business over the internet. According to United Nations data, intra firm trade makes up around $30 \%$ of global trade altogether. The laws regulating transfer pricing are different for each country, requiring that cross border transactions between related parties comply with arm's length price. Simply put, this price should mirror the proposed or applied price between non-related parties in an open market [9].

A fine case of applying this benefit of Blockchain is a container-load of goods whose juridical claim is shifted while the goods are in transition (so-called transfer pricing). So, we should exercise competent jurisdiction who sets the rates and imposes VAT or GST depending on the concrete allocation of goods and terms of its arrangement on some region. Also, it's necessary to highlight while the shift of ownership held the place.

The aforementioned problem usually occurs in chain transactions, for instance, including oil and different products, where ownership in the goods may switch several times within dispatch and arrival. Smart contracts could assist to resolve the permanent time-of-supply dilemma, especially for cross-border trades [3].

For automation of this method, "smart" products or devices can be applied. This could be useful, because they correspond with one another, and to inform their status and location using the internet. That enables the aforementioned tools to validate when any specific terms in an agreement have been reached, so triggering payment and the formulation of the following block.

\section{CONCLUSIONS}

Blockchain development is now at an early stage and many issues, exemplified as regulative ones, have not to be solved yet. Technology is used in cryptocurrencies, the issue of transferring it onto a more complex system, i.e. taxes, is still a work in progress. Blockchain implementation is an ongoing process but its already showing many benefits. Digitalization of the tax system is gaining speed, for developed countries adopting various electronic tax reporting and just developing as well.
It could be more efficient to work with large businessestaxpayers in order to "set a new way and roll-forward" of paying taxes and then involve SMEs and individuals. Cooperation with large taxpayers will also contribute to solving the issue with VAT, the largest budgets income part. Alongside it would be possible to lower a tax burden. In general, this will solve such problems as the tax systems transparency/effectiveness, the actual level of the tax burden, bring more certainty for determining tax base and minimize accounting procedures, clarify control procedures.

Paying taxes is not the main priority when business structures think about this technology. In the focus of research, potential benefits of blockchain could be considered as transactional costs reduction, a more streamlined, efficient and effective tax function. Forming an entirely new tax system around blockchain is the complicated process, the start of which is an estimation of problems that need to be resolved.

\section{References:}

1. OECD (2019), "Technologies for Better Tax Administration. A Practical Guide for Revenue Bodies". Available at: https://read.oecd-ilibrary.org/taxation / technologies-for-better-tax-administration_9789264256439-en\#page14 (Accessed 17 Nov. 2019).

2. PricewaterhouseCoopers (2016), Report "How blockchain technology could improve the tax system". Available at: https://www.pwc.co.uk/issues/futuretax / how-blockchain-technology-could-improve-tax-system.html (Accessed 15 Nov. 2019).

3. EY by Gijsbert Bulk (2018), "How blockchain could transform the world of indirect tax". Available at: https:// www.ey.com/en_gl/trust/how-blockchain-could-transform-the-world-of-indirect-tax (Accessed 12 Nov. 2019).

4. EY (2018), "Worldwide electronic invoicing survey". Available at: https://www.ey.com/Publication / vwLUAssets /ey-Worldwide-electronic-invoicing-survey2018/\$File/ey-Worldwide-electronic-invoicing-survey2018.pdf (Accessed 2 Nov. 2019).

5. Darwin Recruitment (2019), "BLOCKCHAIN REAL TIME TAX (IS THIS THE FUTURE?)". Available at: https:/ / www.darwinrecruitment.com/blog/2017/08/blockchainreal-time-tax-is-this-the-future (Accessed 7 Nov. 2019).

6. Invest in Blockchain (2019), "Canada Adoption: First Town Approves Paying Taxes With Bitcoin - What's Next In Line?". Available at: https://www.investinblockchain.com/canada-adoption-first-town-approves-paying-taxeswith-bitcoin-whats-next-in-line / (Accessed 3 Nov. 2019).

7. Bitfury Exonum (2019), "Extensible framework for blockchain projects". Available at: https://exonum.com / setam (Accessed 30 Oct. 2019).

8. LH-crypto, Cross Market Platform (2019), "The development of the blockchain in the banking business". Available at: https://www.Ih-crypto.com/articles/thedevelopment-of-the-blockchain-in-the-bankingbusiness.html (Accessed 12 Oct. 2019).

9. Deloitte (2017), Blockchain and its potential in taxes. Available at: https://www2.deloitte.com/content/dam/Deloitte/pl/Documents/Reports/pl_Blockchain-technology-and-its-potential-in-taxes-2017-EN.PDF (Accessed 19 Nov. 2019).

Стаття надійшла до редакцї̈ 27.11.2019 p. 